\title{
PENGARUH PEMBERIAN KEFIR SUSU SAPI TERHADAP KADAR KOLESTEROL TOTAL TIKUS JANTAN SPRAGUE DAWLEY
}

\author{
Finta Wahdania, Adriyan Pramono*) \\ Program Studi Ilmu Gizi Fakultas Kedokteran Universitas Diponegoro \\ Jl.Dr.Sutomo No.14, Semarang, Telp (024) 8453708, Email : gizifk@undip.ac.id
}

\begin{abstract}
Background : A high serum cholesterol level might become one of contributing risk factor for development of cardiovascular disease (CVD). Serum cholesterol level could decreased by acid lactic bacteria (ALB) content. Kefir, one of probiotic product have been claimed as a cholesterol-lowering agent. The purpose of this research was to determine effect of cwo milk kefir to serum total cholesterol level in animal model.

Method : true-experimental by using pre post test with randomized control group design. Twenty eight male Sprague dawley rat were divided into four group $(K, P 1, P 2, P 3)$ and induced by high cholesterol diet. Intervention started from 1,5 ml; $2 \mathrm{ml}$ and $3 \mathrm{ml}$ of kefir respectively to P1, P2 and P3 for fifteen days. Cholesterol level was examined by CHOD-PAP method. Data was examined by using one way ANOVA.

Result : Total cholesterol level decreased significantly in all group but there is no defference between group. The highest reduction of total cholesterol was 31,45\%, found in group P3 followed by 31,40\% for K; 30,90\% for P2 and $27,04 \%$ for $P 1$.

Conclusion : kefir administration did not contribute in lowered total cholesterol level, result of this study did not support administration of kefir as a cholesterol-lowering agent.
\end{abstract}

Keyword : kefir ; total cholesterol

\begin{abstract}
ABSTRAK
Latar Belakang : Tingginya kadar kolesterol merupakan salah satu faktor pencetus kejadian penyakit kardiovaskuler. Produk probiotik diketahui mampu menurunkan kadar kolesterol karena mengandung bakteri asam laktat (BAL). Kefir, salah satu produk probiotik yang kaya akan kandungan BAL dan diklaim memiliki efek hipokolesterolemik. Penelitian ini bertujuan untuk mengetahui pengaruh kefir terhadap kadar kolesterol total tikus percobaan.

Metode : Penelitian true eksperimental dengan pre post test with randomized control group design. Sebanyak 28 ekor tikus putih (Rattus novergicus) galur Sprague dawley dibagi menjadi empat kelompok $(K, P 1, P 2, P 3)$ dan diinduksi dengan pakan tinggi kolesterol selama 15 hari dilanjutkan dengan pemberian kefir 1,5 ml;2 $\mathrm{ml}$ dan 3 ml/hari untuk kelompok P1, P2 dan P3selama 15 hari. Kadar kolesterol diperiksa dengan metode CHOD-PAP. Analisis data menggunakan uji beda one way ANOVA.

Hasil : Terjadi penurunan bermakna rerata kadar kolesterol total tikus semua kelompok, namun perbedaan kadar kolesterol total antar kelompok tidak bermakna. Kelompok P3menunjukkan penurunan kadar kolesterol total tertinggi (31,45\%), diikuti kelompok K (31,40\%), P2 (30,9\%) dan P1 (27,04\%).

Kesimpulan : pemberian kefir tidak terbukti menurunkan kolesterol. Hasil penelitian ini tidak mendukung kefir sebagai alternatif penurun kolesterol.
\end{abstract}

Kata kunci : kefir; kolesterol total

\section{PENDAHULUAN}

Penyakit kardiovaskuler (PKV) terutama penyakit jantung koroner (PJK) merupakan penyebab utama kematian di dunia. ${ }^{1}$ Di Indonesia, data Riskesdas 2007 menunjukkan prevalensi PKV berkisar antara 2,6\% di Lampung hingga 12,6\% di NAD dan proporsi kematian akibat penyakit ini mencapai $4,6 \%{ }^{2}$ Hiperkolesterolemia atau kadar kolesterol darah melebihi $200 \mathrm{mg} / \mathrm{dl}$ diduga merupakan salah satu faktor risiko terjadinya PKV. Penelitian di Medan pada tahun 2011 menunjukkan dalam kurun waktu 2009 hingga 2010, angka kejadian hiperkolesterolemia pada penderita PJK mengalami peningkatan dari $13,5 \%$ menjadi $19,2 \%$. $^{3}$

Kadar kolesterol darah yang normal dapat dicapai dengan usaha modifikasi diet yang tepat, antara lain dengan membatasi konsumsi makanan yang mengandung kolesterol dan lemak jenuh yang tinggi. ${ }^{4}$ Pendekatan lain yang potensial adalah dengan konsumsi produk probiotik. Produk makanan probiotik yang telah berkembang adalah susu fermentasi. Beberapa penelitian melaporkan bahwa konsumsi produk susu fermentasi dapat 
menurunkan kadar kolesterol, baik pada hewan maupun manusia. ${ }^{5,6,7,11,12,13}$ Salah satu jenis susu fermentasi yang digunakan sebagai antihiperkolesterolemik adalah kefir. Bahan baku pembuatan kefir adalah susu sapi, kambing atau domba, yang difermentasikam dengan sejenis starter yang disebut kefir grain. Kefir grain terdiri dari bakteri asam laktat (BAL) dan khamir. Konsumsi BAL merupakan salah satu cara yang dapat digunakan untuk menurunkan kadar kolesterol darah. Efek pemberian produk susu fermentasi yang mengandung kultur BAL terhadap kadar kolesterol mencit, tikus dan manusia telah banyak diteliti, namun mekanisme terkait penurunan kolesterol belum dimengerti sepenuhnya. Selama ini, penurunan kadar kolesterol diduga berkaitan dengan mekanisme asimilasi kolesterol dan dekonjugasi garam empedu. ${ }^{6,7,12,13,14}$

Penelitian ini bertujuan untuk mengkaji apakah pemberian kefir berbagai dosis mampu mengubah kadar kolesterol total serum tikus putih. Dari penelitian ini diharapkan dapat membuktikan potensi kefir sebagai pangan fungsional yang bersifat hipokolesterolemia.

\section{METODE}

\section{Sampel}

Sampel yang digunakan dalam penelitian ini adalah tikus putih (Rattus novergicus) galur Sprague dawley berjenis kelamin jantan, berusia 6 minggu, berat badan $80-100$ gram, dan diperoleh dari Laboratorium Hewan Percobaan Pusat Pengujian Obat dan Makanan Nasional.

\section{Bahan}

Bahan yang digunakan adalah kefir susu sapi yang terbuat dari susu sapi segar dan ditambahkan starter kefir grain $7 \%$ lalu difermentasikan selama 24 jam. ${ }^{16}$ Pakan standar rodentia terbuat dari tepung jagung $31 \%$, bungkil gandum (wheaf pollard) 20\%, bungkil kedelai (soy bean meal) $15 \%$, tepung ikan (fish meal) $12 \%$, bungkil kelapa (coconut oil) $8 \%$, bungkil wijen (sesame meal) 5\%, tepung daun singkong (cassava leaf) 8\%, vitamin (premix). Dalam 100 gram pakan standar mengandung protein $22,87 \%$, lemak $0,44 \%$, karbohidrat $32,67 \%$, serat kasar $7,68 \%$ dan kalori 226,12 kal.

\section{Metode penelitian}

Penelitian ini berjenis true experimental dengan desain penelitian pre post test with randomized control group design. Perlakuan yang diberikan adalah pemberian kefir susu sapi, sedangkan yang akan dilihat keluarannya adalah kadar kolesterol total serum tikus.

Tikus diadaptasi dengan lingkungan barunya di dalam ruangan bersuhu $20-22^{\circ} \mathrm{C}$, kelembaban 60 - 70\% dan kandang individu berukuran 41,5 x 29,5 x $20 \mathrm{~cm}$. Selanjutnya seluruh tikus diinduksi dengan pakan tinggi kolesterol berupa larutan otak sapi sebanyak 2 $\mathrm{ml} /$ tikus/hari selama 15 hari. Selanjutnya tikus dikelompokkan menjadi 4 kelompok perlakuan dengan randomisasi, masing-masing 7 ekor. Kelompok K sebagai kontrol diberi pakan standar, kelompok P1 diberikan pakan standard an kefir 1,5 ml; kelompok P2 diberikan pakan standard an kefir $2 \mathrm{ml}$ dan kelompok P3 diberikan pakan standar dan kefir $3 \mathrm{ml}$.

Sampel darah diambil pada hari ke-7 (awal) sebanyak $2 \mathrm{ml}$ kemudian di-centrifuge untuk mendapatkan serumnya dengan kecepatan $3000 \mathrm{rpm}$ selama 5 menit. Pengambilan darah dengan prosedur yang sama diulang pada hari ke21 (sebelum) hari dan hari ke-36 (setelah). Kadar kolesterol total serum tikus diperiksa di Balai Besar Laboratorium Kesehatan (BBLK) Jakarta dengan metode CHOD-PAP.

Data dari hasil penelitian dianalisis secara statistic menggunakan analisis sidik ragam One way ANOVA. Perbedaan dianggap bermakna pada tingkat $\mathrm{p}<0,05$.

\section{HASIL \\ Perubahan Kadar Kolesterol Total Sebelum dan Setelah Pemberian Pakan Tinggi Kolesterol}

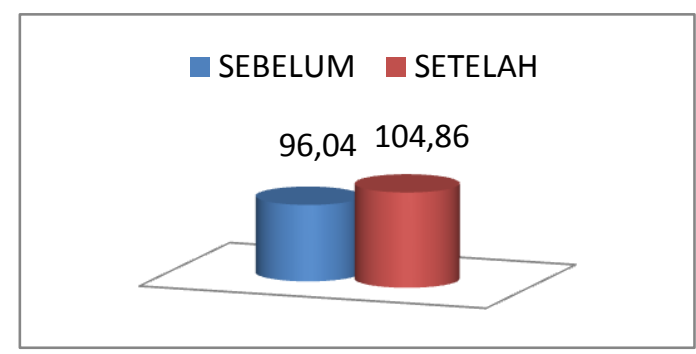

Gambar 1. Kadar Kolesterol Sebelum dan Setelah Pemberian Pakan Kolesterol (mg/dl) 
Pada Gambar 1 terlihat bahwa terjadi peningkatan kadar kolesterol total pada semua kelompok setelah pemberian pakan kolesterol. Rerata kadar kolesterol sebelum pemberian pakan kolesterol adalah 96,04 mg/dl dan rerata kadar kolesterol setelah pemberian pakan kolesterol adalah 104,86 mg/dl. Secara keseluruhan, peningkatan yang terjadi adalah sebesar 9,2\% .
Peningkatan kadar kolesterol setelah pemberian pakan kolesterol tidak bermakna apabila dibandingkan dengan sebelum pemberian pakan tinggi kolesterol $(\mathrm{p}=0,07)$

\section{Perubahan Kadar Kolesterol Total Sebelum dan Setelah Pemberian Kefir}

Tabel 4. Rerata perubahan kadar kolesterol total antar kelompok sebelum dan setelah pemberian kefir

\begin{tabular}{|c|c|c|c|c|c|}
\hline \multirow{2}{*}{$\begin{array}{c}\text { Kelompo } \\
\mathbf{k}\end{array}$} & \multirow[t]{2}{*}{$\mathbf{N}$} & \multicolumn{3}{|c|}{ Rerata \pm Simpang Baku } & \multirow[t]{2}{*}{$p$} \\
\hline & & Sebelum & Sesudah & $\Delta$ & \\
\hline $\mathrm{K}$ & 7 & $\begin{array}{c}103,71 \pm \\
11,25\end{array}$ & $\begin{array}{c}71,14 \pm \\
10,85\end{array}$ & $32,57 \pm 9,01^{\mathrm{a}}$ & $0,675^{* *}$ \\
\hline $\mathrm{P} 1$ & 7 & $99,86 \pm 17,61$ & $72,86 \pm 8,20$ & $27,00 \pm 15,46^{\mathrm{a}}$ & \\
\hline $\mathrm{P} 2$ & 7 & $\begin{array}{c}109,57 \pm \\
13,07\end{array}$ & $75,71 \pm 8,20$ & $33,86 \pm 6,82^{\mathrm{a}}$ & \\
\hline $\mathrm{P} 3$ & 7 & $\begin{array}{c}106,29 \pm \\
17,98\end{array}$ & $\begin{array}{c}72,86 \pm \\
12,17\end{array}$ & $33,43 \pm 11,42^{\mathrm{a}}$ & \\
\hline
\end{tabular}

Keterangan :

${ }^{\mathrm{a}, \mathrm{b}}$ nilai yang disertai notasi yang sama menunjukkan perbedaan yang tidak nyata pada uji lanjut LSD

** tidak ada perbedaan bermakna antar kelompok

Tabel 4 menunjukkan kadar kolesterol total sebelum dan setelah pemberian kefir. Penurunan kolesterol tertinggi terjadi pada kelompok P3 sebesar 31,45\%, diikuti K $(31,40 \%)$, P2 $(30,9 \%)$ dan P1 $(27,04 \%)$. Namun kadar kolesterol ketiga kelompok perlakuan tidak memiliki perbedaan yang bermakna bila dibandingkan dengan kelompok kontrol $(p>0,05)$.

\section{PEMBAHASAN}

Kadar Kolesterol Total Setelah Pemberian Pakan Tinggi Kolesterol

Hasil penelitian ini menunjukkan terjadinya peningkatan kadar kolesterol total setelah pemberian otak sapi selama 15 hari. Kondisi yang menunjukkan adanya peningkatan kolesterol total di dalam darah diketahui sebagai keadaan hiperkolesterolemia. ${ }^{17}$ Di dalam usus, lemak yang berasal dari makanan mengalami pemecahan menjadi asam lemak bebas, fosfolipid, trigliserida dan kolesterol. Bersama kolesterol tak ter-esterisfikasi, kolesterol ini kemudian masuk ke dalam kilomikron untuk disalurkan ke hati. Sebagian besar kolesterol akan dieksresikan hati dalam bentuk VLDL. Di dalam darah, VLDL yang bermuatan triasilgliserol, kolesterol dan ester kolesterol akan dimetabolisme menjadi IDL. Kandungan triasilgliserol dalam IDL akan mengalami hidrolisis menjadi asam lemak bebas dan gliserol, sehingga akan terbentuk LDL yang kaya akan kolesterol dan esternya. Kolesterol yang terdapat dalam LDL mengandung ikatan tidak jenuh yang rentan terhadap reaksi peroksidasi oleh radikal bebas. Peningkatan kolesterol terjadi karena penyerapan LDL oleh reseptor LDL menuju membran sel, sintesis kolesterol dan hidrolisis ester kolesterol oleh enzim ester kolesterol hidrolase. ${ }^{9}$

Dalam penelitian ini, peningkatan kadar kolesterol menunjukkan perbedaan yang tidak bermakna dengan kadar kolesterol sebelum pemberian pakan tinggi kolesterol. Hal ini diduga karena adanya mekanisme regulasi dalam tubuh yang berupa pembatasan sintesa kolesterol oleh hati dengan menghambat HMGCoA yang esensial untuk biosintesa kolesterol, peningkatan enzim Cholesterol Acyl Transferase (ACAT) yang akan menyimpan kelebihan kolesterol ini menjadi ester kolesterol atau penurunan sintesa reseptor LDL untuk mengurangi pemasukan kolesterol dan proteksi dari akumulasi kolesterol. ${ }^{10}$

\section{Kadar Kolesterol Total Setelah Pemberian Kefir}

Dalam penelitian ini, kefir diharapkan mampu menurunkan kadar kolesterol total serum melalui mekanisme asimilasi kolesterol dan dekonjugasi garam empedu oleh BAL. ${ }^{6,7,12,13,14}$ Asimilasi kolesterol diduga terjadi melalui 
pengikatan kolesterol pada membran sel bakteri yang menempel pada mukosa usus sehingga membran seluler BAL lebih tahan terhadap lisis dan terjadi penurunan jumlah kolesterol bebas yang diabsorbsi. ${ }^{11,12}$ Pada mekanisme dekonjugasi garam empedu, garam empedu yang merupakan prekursor kolesterol diubah menjadi bentuk yang sulit untuk diabsorbsi dengan bantuan enzim bile salt hidrolase (BSH), sehingga harus dieksresikan melalui feses. Setiap harinya, kurang dari 5\% garam empedu yang masuk ke usus keluar melalui feses. Inti steroid tidak dapat diuraikan dalam tubuh, sehingga eksresi garam empedu merupakan jalur utama pembuangan inti steroid dan kolesterol dari dalam tubuh. ${ }^{9}$

Beberapa hasil penelitian menunjukkan bahwa jumlah probiotik $10^{7}$ hingga $10^{9} \mathrm{cfu} / \mathrm{g}$ pada hewan dapat menurunkan 22,6 $-27,9 \%$ kadar kolesterol. $^{15}$ Walaupun kefir yang digunakan mengandung jumlah probiotik yang cukup untuk aktifitas hipokolesterolemia $\left(7,6 \times 10^{7} \mathrm{cfu} / \mathrm{g}\right)$, akan tetapi dalam penelitian ini perlakuan kefir tidak berkontribusi dalam menurunkan kolesterol. Setelah masa pemberian kefir, penurunan kadar kolesterol total terjadi pada kelompok kontrol dan kelompok perlakuan. Diduga terdapat faktor eksternal yang mempengaruhi penurunan kolesterol pada semua kelompok, antara lain komposisi pakan standar. Di dalam pakan standar, terdapat asam amino, terutama lisin dan metionin yang terkandung dalam tepung ikan. Tepung ikan digunakan untuk mengganti defisiensi asam amino metionin dalam bungkil kedelai dan lisin dalam bungkil kelapa. ${ }^{19}$ Lisin dan metionin merupakan prekursor pembentukkan karnitin. Di dalam mitokondria, karnitin merangsang proses $\beta$ oksidasi asam lemak rantai panjang sehingga timbunan lemak dalam bentuk kolesterol dapat ditekan. $^{8}$

Kadar kolesterol total kelompok P1,P2 dan P3 tidak berbeda bermakna dengan kadar kolesterol total kelompok K $(p>0,05)$. Diduga kandungan lemak dalam pakan dan kefir menjadi salah satu penyebab tidak bermaknanya perbedaan tersebut. ${ }^{5}$ Komposisi lemak kefir tergantung dari susu yang digunakan sebagai bahan bakunya. ${ }^{18}$ Bahan baku kefir dalam penelitian ini adalah susu sapi yang mengandung kadar lemak 4,156\% dan kefir yang dihasilkan mengandung kadar lemak sebesar $1,904 \%$. Sedangkan dalam 100 gram pakan standar mengandung 0,44\% lemak. Lemak dari makanan serta asam lemak hasil sintesis de novo akan menghasilkan asam lemak rantai panjang. Asam lemak ini akan dioksidasi menjadi asetil
KoA. Asetil KoA merupakan prekursor pembentuk kolesterol dan steroid lain. ${ }^{9}$

\section{SIMPULAN DAN SARAN}

Hasil akhir dalam penelitian ini menunjukkan bahwa perlakuan kefir tidak terbukti dapat menurunkan kolesterol. Penurunan kadar kolesterol terjadi pada semua kelompok, termasuk kelompok kontrol yang hanya diberikan pakan standar. Untuk penelitian selanjutnya disarankan menggunakan kefir berbahan baku susu rendah lemak dengan konsentrasi kefir grain yang berbeda-beda dalam volume yang sama.

\section{DAFTAR PUSTAKA}

1. Mahan LK, Escott-Stump S. Krause's food and nutrition therapy. ed $12^{\text {th }}$. Philadelphia: Elsevier; 2008.p.833-860.

2. Badan Penelitian dan Pengembangan Kesehatan. Riskesdas 2007. Jakarta: Departemen Kesehatan RI. 2008.

3. Soraya PK. Prevalensi Hiperkolesterolemia Pada Pasien Dengan Penyakit Jantung Koroner di RSUP H. Adam Malik Tahun 2009-2010. Medan : Universitas Sumatera Utara. 2011.

4. Iman S. Penyakit Jantung koroner dan serangan jantung. Jakarta: Gramedia Pustaka Utama; 2002.p.260-264.

5. St-Onge MP, Farnworth ER, Savard T, Chabot D, Mafu A, Jones PJH. Kefir consumption does not alter plasma lipid levels or cholesterol fractional synthesis rates relative to milk in hyperlipidemic men: a randomized controlled trial. Biomed Central. 2002;2(1).

6. Ceneziz S, Yaman H, Ozcan A, Kart A, Karademir G. Effects of kefir as a probiotic on serum cholesterol, total lipid, aspartate amino transferase and alanine amino transferase activities in broiler chicks. Medycyna Wet. 2008;64(2):168-170.

7. Ari Y. Pengaruh pemberian susu fermentasi lactobacillus casei strain shirota terhadap perubahan kadar fraksi lipid serum tikus hiperkolesterolemi (Tesis). Semarang: Universitas Diponegoro. 2004.

8. Eli R, Deri A, Alfajri, Dwi T,Surya SP. Upaya Penurunan Lemak Tubuh Ayam Broiler Melalui Penambahan Metionin dan Lisin sebagai Prekursor Karnitin dalam Ransum. Padang: Universitas Andalas. 2003.

9. Murray RK, Granner DK, Rodwell VW, Pendit BU, Wulandari N. Biokimia harper. $27^{\text {th }}$ ed. Jakarta: EGC; 2009.p.225-254.

10. Guntari TM, Hastari W. Efek Ransum Kolesterol Tinggi Terhadap Rasio Oksidan dan Antioksidan pada Tikus Sprague dawley. J.Sains Vet. 2004;22:2.

11. St-Onge MP, Farnworth ER, Jones PJH. Consumption of fermented and nonfermented 
dairy products: effects on cholesterol concentrations and metabolism. Am J Clin Nutr. 2000;71:674-681.

12. Riyanto S. Pengaruh pemberian yogurt kedelai hitam (black soygurt) terhadap profil lipid tikus hiperkolesterolemia. Semarang : Universitas Diponegoro. 2011.

13. Sulistyowati. Pemanfaatan yogurt sebagai bahan penurun trigliserida darah manusia. Wahana. 2008;51(2):18-26.

14. Netty K, Betty SLJ, Siswa S, Hariyadi RD. Seleksi bakteri asam laktat indigenous sebagai galur probiotik dengan kemampuan menurunkan kolesterol. Jurnal Mikrobiologi Indonesia. 2003; 8(2):39-42.

15. Ooi LG, Liong MT. Cholesterol Lowering Effects of Probiotics and Prebiotics: A Review of in Vivo Amd in Vitro Findings. Int J Mol Sci. 2010;11: 2499-2522.

16. Purnomo H, Muslimin LD. Chemical Characteristics of Pasteurised Goat Milk and Goat Milk Kefir Prepared Using Different Amountof Indonesian Kefir Grains and Incubation Times. Int Food Research J. 2012;19(2):791-794.

17. A Yuniastuti. Efek Hipokoleserolemi Lactobacillus Acidophilus D2 dari Susu Fermentasi Pada Tikus. J Indon Trop Agric. 2004; 29(2):69 - 75.

18. Manik ES. Kajian Konsentrasi Kefir Grain dan Lama Simpan dalam Refrigerator terhadap Kualitas Kimiawi Kefir Rendah Lemak. Jurnal Ilmu-ilmu Peternakan;21(1):24-30.

19. Dendy V, Lilis K, Dwierra EA. Suplementasi Tepung Ikan dan Bungkil Kelapa dalam Ransum Akhir Kebutingan Terhadap Performa Reproduksi Induk dan Pertumbuhan Anak Pra Sapih Domba Lokal. Bogor : Institut Pertanian Bogor. 2011. 